\title{
«El rastro de mis hazañas os servirá de guía». Las partituras de Manuel Nieto y Manuel Fernández Caballero para el III centenario del Quijote de 1905 en el Teatro Real*
}

\author{
ANDREA GARCÍA TORRES**
}

\begin{abstract}
Resumen
Este artículo examina las dos únicas partituras localizadas que se estrenaron con motivo de la celebración del III centenario de la publicación de la primera parte del Quijote en el Teatro Real en 1905. A partir del preludio sinfónico para El Caballero de los Espejos, compuesto por Manuel Nieto (1844-1915) y del Homenaje a Cervantes, de Manuel Fernández Caballero (1835-1906), se discuten cuestiones formales de las obras en términos musicales, su funcionalidad en el centenario, la inserción de ambas composiciones en la tradición musical decimonónica y sus peculiaridades a la hora de representar musicalmente los intereses nacionales del tricentenario.
\end{abstract}

Palabras clave: Quijote; Cervantes; III centenario; Teatro Real; regeneracionismo; Manuel Fernández Caballero; Manuel Nieto.

Title: «El rastro de mis hazañas os servirá de guía». The Scores of Manuel Nieto and Manuel Fernández Caballero for the Third Quixote Centenary in the Teatro Real in 1905

\footnotetext{
Abstract

This article examines the only two located scores that were performed for the first time on the occasion of the III centenary of the Quixote first part publication celebrated in the Teatro Real in 1905. From the prelude for El Caballero de los Espejos, written by Manuel

* Este trabajo se ha realizado en el marco del Proyecto PGC2018-098986-B-C32, «Microhistoria de la música española contemporánea: periferias internacionales en diálogo» (2019-2022), desarrollado por el grupo de investigación ERASMUSH de la Universidad de Oviedo.

** Universidad de Oviedo. garciatandrea@uniovi.es / ORCID iD: https://orcid.org/0000-0003-0941-6283
} 
Nieto (1844-1915), and the Homenaje a Cervantes by Manuel Fernández Caballero (18351906), formal questions of the plays in music terms, their functionality in the centenary, the insertion of both compositions in the nineteenth-century music tradition, and their peculiarities to musically represent the national interests of the tricentennial have been discussed.

Keywords: Quixote; Cervantes; Third Centenary; Teatro Real; Regeneracionism; Manuel Fernández Caballero; Manuel Nieto.

\section{Cómo citar este artículo / Citation}

García Torres, Andrea. 2021. «"El rastro de mis hazañas os servirá de guía”. Las partituras de Manuel Nieto y Manuel Fernández Caballero para el III centenario del Quijote de 1905 en el Teatro Real».Anales Cervantinos 53: 85-112. https://doi.org/10.3989/anacervantinos.2021.003

\section{INTRODUCCIÓN}

El Quijote experimentó en los primeros años del siglo XX un interés exponencial desde numerosas disciplinas artísticas, lideradas por autores dentro del ámbito literario como Unamuno, Maeztu o Ganivet, quienes además respaldaron el III centenario de la publicación de su primera parte en 1905, si bien expusieron públicamente sus opiniones y críticas sobre los acontecimientos conmemorativos y cómo la celebración debería revertir en la sociedad coetánea de una forma más provechosa.

Los intelectuales coetáneos señalaron el Quijote como «motor espiritual [...] y símbolo del afán reformador y regeneracionista» (Pascual 1999, 143144), vieron en él un medio para despertar el pensamiento crítico sobre la situación del país. Unamuno une el débil patriotismo de España durante el cambio de siglo con la banalidad con la que se referencia al Quijote (1917, 217). Su preocupación se justifica por la equiparación que se hizo de Cervantes y el Quijote en los años del cambio de siglo cuando, en su opinión, no solamente no estaban al mismo nivel, sino que representaban lo contrario al contraponer "lo eterno y universal" del personaje con lo "temporal y particular" de reducir el Quijote a una obra literaria supeditada a su autor, y expresaba la decadencia nacional en términos como «nos falta quijotismo tanto cuanto nos sobra cervantismo» (Unamuno 1916, 215-217). Precisamente para apaciguar este debate, la intención de los organizadores del centenario de 1905, José Ortega Munilla y Octavio Picón, era la de conmemorar el personaje sobre el autor (Storm 1998, 634). En el homenaje celebrado en el Teatro Real como parte de los actos de este centenario, la ambivalencia a la que se refiere Unamuno queda manifiesta en la loa y el himno a los que el compositor Manuel Fernández Caballero puso música, que alaban a Cervantes y al 
Quijote a partes iguales mientras proclaman para la nación un porvenir ligado al del héroe.

Para Pérez Galdós, el tricentenario buscaba recuperar el «brillante pasado cultural de España» en contraposición de la debacle colonial, al utilizar el gobierno conservador la novela y a su autor con la finalidad de potenciar la unidad nacional frente al auge de los nacionalismos periféricos (Pérez-Magallón 2020, 124-125). Storm (1998) también sostiene el interés imperante por mejorar la imagen del país cuando detalla la artificiosidad de los actos conmemorativos celebrados en Madrid para el centenario. El homenaje celebrado en el Teatro Real el 10 de mayo, el último de los actos programados, se orientó en esa misma línea festiva de exaltación y propaganda nacional, que hace gala de patrioterismo y demostró una conciencia crítica inexistente sobre la situación de España tras el cambio de siglo. No son de extrañar entonces las críticas de los mencionados autores e intelectuales sobre el transcurso de las actividades y su escasa repercusión social.

La función celebrada el 10 de mayo de 1905 en el Teatro Real fue uno de los actos del III centenario que más atención ha recibido, hasta el punto de que se ha documentado desde la perspectiva musicológica, como es el caso de Adela Presas (2007, 285-306) y de López (2017, 325-342), y también desde los estudios históricos (Storm 1998, 625-654) y literarios, como los de Vega (2006a; 2006b) y López Roldán (2005), donde se estudian las representaciones teatrales y coinciden con Unamuno en su crítica a la escasa calidad con la que se abordó la novela cervantina. La cobertura mediática del centenario (Chaparro 2013) arroja algunas hipótesis comunes sobre cuestiones nacionales que coinciden con este estudio. No obstante, estaba aún pendiente un estudio sobre las partituras estrenadas el 10 de mayo de 1905, su edición y recuperación, en línea con los trabajos realizados sobre las obras literarias ${ }^{1}$. De forma más general, la música de tema quijotesco ha sido objeto de diversos estudios académicos, entre los que destacan los realizados por Cabrera (2019, 81-88), Lolo y Presas (2014, 153-166), Morales (2011, 639-650), Lolo (2006, 317-332; 2007; 2010, 83-108), Weber (2005, 1743-1756) o Pastor $(2005,19-24)^{2}$, pero su presencia se reduce considerablemente al hacer referencia a las composiciones escritas ex profeso para las conmemoraciones cervantinas.

Los trabajos previos que se centran en la música del III centenario lamentan la falta de las partituras estrenadas en 1905 en el homenaje cervantino en el Teatro Real, abordadas en este trabajo y localizadas en el Archivo de Mú-

1. Son ejemplo de ello las ediciones de Los galeotes. Comedia en cuatro actos, de Joaquín y Serafín Álvarez Quintero (1911) y El Caballero de los Espejos de Ramos Carrión, publicado por Luciano García Lorenzo (2012). Si bien es cierto que no se ha localizado ninguna edición del cuadro La vela de armas de Sellés.

2. Además, para obtener una bibliografía más extensa sobre la repercusión que la novela cervantina tuvo en el ámbito musical, dentro y fuera del ámbito hispánico, puede consultarse $E l$ Quijote en la música del Centro Virtual Cervantes: <https://cvc.cervantes.es/actcult/quijote_musica/ bibliografia.htm>. 
sica del Museo Nacional de Teatro, tan solo de forma parcial ${ }^{3}$. En el caso del preludio escrito por Manuel Nieto (1844-1915), únicamente ha podido datarse la partitura general autógrafa y varias partes instrumentales, todas ellas pertenecientes a un preludio y un final escritos por el compositor Manuel Nieto para enmarcar el episodio de El Caballero de los Espejos, adaptado a la escena por Miguel Ramos Carrión. El mismo archivo custodia también una supuesta loa y un himno titulado Homenaje a Cervantes, con letra de Carlos Fernández Shaw (1865-1911) y música de Manuel Fernández Caballero (1835-1906). No se conoce el paradero de los otros dos preludios escritos para el homenaje cervantino por Amadeo Vives (1871-1932) y Tomás Bretón $(1850-1923)^{4}$ para las adaptaciones de La vela de armas y La aventura de los galeotes respectivamente.

La intención de este artículo es analizar las dos partituras localizadas de la celebración quijotesca en el Real, cuyo valor reside no solo en aumentar la nómina de composiciones musicales que giran en torno al Quijote, sino en enfatizar las particularidades que llevan implícitas en el uso de recursos compositivos y observar los intereses político-nacionales que se promulgaron durante el centenario en el Real, amparado en los moldes del teatro decimonónico.

\section{EL III CENTENARIO DEL QUiJOTE EN MADRID. LA CULMINACIÓN DE LAS FESTIVIDADES EN EL TEATRO REAL}

Las expectativas para la celebración del III centenario del Quijote eran muy elevadas por las connotaciones de resurgimiento y de reanimación nacional que llevaba asociadas (Sawa y Becerra 1905). España experimentaba a comienzos del siglo XX una exaltación nacional que se dejó notar de forma evidente con acontecimientos como la coronación de Alfonso XIII en 1902 (Moreno 2007, 269-294), y este tercer centenario mantiene ese mismo espíritu. Los propósitos nacionalistas tras las celebraciones del homenaje cervantino enlazan con lo expuesto sobre nacionalismo por Ernest Geller (O'Learly 2000, 122), quien observó cómo la creación de identidades nacionalistas era aprovechada por las élites. Precisamente es lo que sucede en el homenaje al Quijote celebrado en el Teatro Real, en el que las obras representadas en el programa coinciden en utilizar la historia de España, y en particular a Cervantes y al Quijote, para alinearse con el nacionalismo am-

3. Las dos partituras abordadas en este trabajo están recogidas en las siguientes signaturas: Manuel Nieto: Preludio para El Caballero de los Espejos, Archivo del Museo del Teatro de Almagro [sig. Partitura 770]; Manuel Fernández Caballero: Loa e Himno Homenaje a Cervantes, Archivo del Museo del Teatro de Almagro [Sig. Partitura 800, cajas n. ${ }^{\text {os }} 1$ y 2].

4. La monografía sobre Tomás Bretón escrita por Víctor Sánchez (2002) es el trabajo más completo que existe sobre el músico, pero cuando hace referencia a su participación en el III centenario no da ninguna pista sobre la localización de la partitura. 
parado en la nostalgia histórica, utilizando ese motor espiritual en beneficio de la apología nacional. Las conmemoraciones por el III centenario se ajustan muy bien al nacionalismo de estado denominado por Fusi (2003), característico del siglo XIX, que apelaba a las ideas de grandeza nacional siempre desde una perspectiva sentimental capaz de abarcar desde textos legales y constitucionales hasta conmemoraciones y festividades, como en este caso. Una «centenariomanía» (Archilés 2008, 77) que se impuso tras el 98 con la intención de generar una conciencia comunitaria amparada en los mitos históricos.

El programa del homenaje celebrado en el Teatro Real se diseñó con la intención de potenciar esa apología de unidad nacional restaurada y el objetivo de que el Quijote fuera el verdadero protagonista gracias a la representación de algunas de sus hazañas más célebres. La velada del Teatro Real presentó inconvenientes en el trascurso de las conmemoraciones y fue pospuesta, ya que estaba prevista en principio para el 9 de mayo de $1905^{5}$. Finalmente se celebró el 10 y el programa lo conformó una sucesión de episodios transcritos y dramatizados de la novela cervantina, además de cuatro oberturas sinfónicas y una apoteosis en honor a Cervantes:

- Sinfonía (obertura) de la ópera Don Giovanni, de Mozart

- Representación del entremés Los dos habladores, de Miguel de Cervantes

- Preludio instrumental, de Amadeo Vives

- Cuadro de La vela de armas, episodio del Quijote adaptado a la escena por Eugenio Sellés

- Preludio instrumental de Tomás Bretón

- Cuadro de Los galeotes, adaptado a la escena por los hermanos Álvarez Quintero

- Preludio instrumental de Manuel Nieto

- Cuadro del encuentro de don Quijote con el Caballero de Los Espejos, adaptado por Miguel Ramos Carrión

- Homenaje a Cervantes. Loa escrita por Carlos Fernández Shaw, con la actriz María Guerrero en el papel de España, seguida de un himno con letra del mismo escritor y música de Manuel Fernández Caballero

La música compuesta para el homenaje cervantino en el Real parece haber tenido una transcendencia residual dentro de las numerosas manifestaciones artísticas desarrolladas durante el centenario, a juzgar por la limitada difusión que tuvieron las obras musicales del centenario tras su estreno, dado que no hubo un plan institucional para conservar, difundir y reprogramar las partituras estrenadas en la función de 1905. Las partituras han sido relegadas a un segundo plano, los materiales conservados en el Archivo del Teatro de Alma-

5. «El centenario de "El Quijote”». El País, Madrid, 10 de mayo de 1905, 2. 
gro son los mismos que utilizaron los profesores de orquesta y el director Enrique Fernández Arbós (Sawa y Becerra 1905, 105-117) para la función del Real, sin atisbo alguno de recuperación. Tanto la música localizada de Manuel Fernández Caballero como la de Manuel Nieto son folios manuscritos que, además de las particelle para los cantantes y los distintos instrumentos que intervinieron además del coro, incluyen una parte de apuntar, en el caso de Fernández Caballero, y una partitura completa, en el de Nieto. Los materiales de Almagro constituyen un trabajo parcial, puesto que parte de las composiciones interpretadas en el Teatro Real sigue sin localizarse.

El 98 y el cambio de siglo no supusieron una fractura inmediata en la composición y representación musical con la tradición decimonónica, y esta premisa se corrobora a la hora de observar las partituras del preludio del Caballero de los Espejos y el Homenaje a Cervantes. Ambas obras son herederas de la tradición compositiva del siglo XIX en lo que a estructuras formales, armonía, orquestación y posición en el transcurso de la jornada se refiere. Los autores que intervinieron en el homenaje del III centenario en el Teatro Real fueron personalidades que gozaron de enorme popularidad antes del término del siglo. Tanto escritores como compositores habían desarrollado gran parte de su actividad en el ámbito teatral finisecular, estableciendo en muchos casos colaboraciones previas. Es lo que ocurrió con Amadeo Vives y Eugenio Sellés, que en 1900 estrenaron La balada de la Luz, uno de los títulos más exitosos de su carrera, pero también Manuel Nieto y Miguel Ramos Carrión habían colaborado de forma puntual en un sainete titulado Coro de señoras, estrenado en 1886, y lo mismo sucedió con Carlos Fernández Shaw y Manuel Fernández Caballero. Es de suponer que siendo ambos autores de teatro y frecuentando las mismas instituciones culturales de la época, existiese entre ellos cierto trato al margen de lo que reflejan sus catálogos. De todas formas, la distribución literario-musical del homenaje en el Real, intercalando la música entre las representaciones teatrales, no exigía en la práctica una estrecha colaboración.

Los citados autores eran personalidades muy influyentes en la vida cultural e institucional madrileña a comienzos de siglo. Tomás Bretón y Manuel Fernández Caballero formaron parte de la Sección de Música de la Academia de Bellas Artes de San Fernando, institución que también se sumó al homenaje del III centenario ${ }^{6}$. Además, sus éxitos anteriores en el ámbito dramático les habían conferido importante reconocimiento. Bretón, quien presentaba una mayor experiencia en materia sinfónica, había estrenado antes de 1905 diversas sinfonías y composiciones orquestales, además de óperas como Los amantes de Teruel (1889) o La Dolores (1895). Por su parte, Fernández Caballero

6. Esta comisión, formada por Fernández Caballero, Bretón y Serrano, en la misma acta de la sesión celebrada el 30 de enero, incluye la orden para celebrar actividades en torno al Quijote. Véase Real Academia de Bellas Artes de San Fernando. Sección de Música, año 1905. Fol. 14v-15r. Accesible en: $\quad<$ http://www.cervantesvirtual.com/obra-visor-din/actas-de-la-sesiones-celebradas-por-la-seccionde-musica-1873-1970-28/html/034ceff0-82b2-11df-acc7-002185ce6064_3.html >. Fecha de acceso: 11 de mayo de 2021. 
y Nieto obtuvieron enormes éxitos con Gigantes y Cabezudos (1898) y Cuadros Disolventes (1896). Aunque más jóvenes, también habían destacado ya entonces Vives con Bohemios (1904) y la comedia Los galeotes (1900) de los hermanos Quintero, que fue estrenada en el Teatro de la Comedia y premiada por la Real Academia Española?

La velada conmemorativa en el Teatro Real recibió numerosas críticas por su organización, cuando tuvo que ser pospuesta porque las entradas no salieron a la venta de forma pública, ya que solo se podía acceder por invitación y por ello fueron numerosos los escritores e intelectuales que no fueron invi$\operatorname{tados}^{8}$. En materia musical, es importante apuntar que la obertura de Don Giovanni de Mozart en el programa del Real es cuestionable y establece una clara desconexión con las demás obras que se interpretaron en esta función, todas sobre tema quijotesco y escritas por autores españoles. La inclusión de esta obertura parece más fruto de la improvisación que de una intención por homenajear al Quijote, a Cervantes o de hacer apología nacionalista. Algunas fuentes coetáneas ${ }^{9}$ comentan que la intención inicial era la de interpretar el poema sinfónico Don Quixote de Richard Strauss, pero finalmente no se produjo y su estreno en la capital fue en 1916.

Si la hoja de ruta de la celebración en el Teatro Real buscaba exaltar lo nacional, habría sido más lógico celebrar el centenario del fallecimiento de Luigi Boccherini, que se cumplía el mismo año de 1905, incluyendo alguna composición suya. La Gazeta informó entonces de que los herederos del compositor habían ofrecido al ministro de Instrucción Pública y Bellas Artes la posibilidad de representar algunas de las obras inéditas de Boccherini a modo de conmemoración ${ }^{10}$; su mayor vinculación con España habría sido quizá más propicia que la obertura de Don Giovanni que se interpretó finalmente.

\section{Preludio para el Caballero de los ESPEJOS EN EL CONTEXTO MUSICAL DEL CENTENARIO Y PARTICULARIDADES DE SU ADAPTACIÓN}

En 1905, el compositor Manuel Nieto se encontraba ya parcialmente retirado de la actividad compositiva, estrenando un número de obras mucho menor con respecto a las décadas anteriores, pero aún seguía participando de forma activa en la vida musical madrileña, como miembro del

7. Es importante no confundir este título con La aventura de los galeotes: adaptación escénica del capítulo XXII de la primera parte del "Quijote" que los mismos autores publicaron con posterioridad, vinculada con el centenario de 1905.

8. «La función del Real suspendida». El Imparcial, 9 de mayo de 1905, 1.

9. Suárez Bravo, F. 1905. «"El Quijote” de Strauss». El Álbum Iberoamericano, 14 de junio de 1905, 4-5.

10. «Primer centenario de la muerte de Luis Boccherini». Gazeta de Madrid, 24 de mayo de $1905,745$. 
Círculo de Bellas Artes, de la junta directiva de la Sociedad de Autores Españoles y como jurado en concursos de composición convocados por el estado.

La participación de Nieto en el centenario pudo deberse a la sustitución de Gerónimo Giménez en el último momento. El Liberal publicó el 18 de abril de 1905 que sería el maestro Giménez quien, en un principio, se encargaría de orquestar el episodio de El Caballero de los Espejos (Cortizo y Sobrino 2010, 155-202). El encargo procedía de la junta organizadora de la Academia de Bellas Artes de San Fernando, que pretendía favorecer la divulgación cervantina a través de una plataforma tan extendida como había sido el teatro al término del siglo XIX, y adjudicar la labor de revisitar la novela a algunos de los autores populares más reconocidos del momento, cuya fama procedía de sus triunfos en el terreno del género chico, que copó la programación teatral madrileña del último tercio del siglo. Se pretendía así adoctrinar al público sobre las andanzas de don Quijote, cuyo conocimiento entre la población media del cambio de siglo se debía más a la tradición popular que a la propia lectura de la novela. Fue precisamente esta condición la que determinó los festejos del centenario y la que provocó las críticas de los intelectuales, previamente comentadas. Se conseguía, con ello, aprovechar la obra de Cervantes para hacer propaganda histórica de las glorias nacionales pasadas e instrumentalizar el teatro lírico y sus autores en favor de la exaltación patriótica en un momento clave, como lo fueron los años sucesivos a la crisis del 98, en que era necesario proyectar una imagen de nación sólida haciendo apología del pasado (Storm 1998, 625-654).

«Lo más importante no era tanto el mensaje ideológico, sino el proceso de concienciación política y nacional de la población» (Encabo 2008, 43), por lo que la recuperación de los héroes históricos, como es el caso del Quijote, encajaba bien con los planteamientos regeneracionistas expuestos por la élite intelectual de la época. Asimismo, entre los intereses del centenario estaban los de fomentar el sentimiento patriótico y la cohesión social, al pretender implicar a sectores populares de la población madrileña en los festejos (Storm 1998, 626). Tampoco consiguió esta implicación con la causa nacional la reposición del mismo programa del Teatro Real días después en el Teatro Español ante un público menos distinguido, a pesar de los propósitos divulgativos de la actriz María Guerrero y su compañía ${ }^{11}$.

La revisión hemerográfica muestra cómo las obras teatrales programadas en la función del Real se representaron unos días más tarde en el Teatro Español de Madrid, aunque aparentemente sin incluir las composiciones musicales, con lo que se refuerza el papel secundario de la música en este acto.

11. «María Guerrero y Fernando Díaz de Mendoza repartieron el total de las localidades entre las representaciones obreras de Madrid, Escuelas Municipales, cigarreras y soldados, y clases de tropa de guarnición», en «Teatro español». La Época, 13 de mayo de 1905, 2. 
La prensa destacó con mucho énfasis la presencia en el Español de numerosos sectores representantes de las clases obreras ${ }^{12}$.

La función del Teatro Real fue una velada en la que el protagonismo recayó mayormente en el aspecto dramático y la música tuvo solo un papel complementario, a pesar de la insistencia de las élites musicales por reivindicar la presencia que la música tuvo en el Quijote. Sus reivindicaciones sí estaban recogidas en el discurso que ofreció el crítico Cecilio de Roda en el Ateneo con motivo del centenario (De Roda 1905, 455-463). En un primer momento estaba previsto que todas las obras líricas representadas estuvieran basadas en episodios del Quijote, una iniciativa cuya propuesta no llegó a cumplirse finalmente (Cortizo y Sobrino 2010, 155-202). Esta afirmación, observable en el programa definitivo de la función del Real, es la que permite, junto al hallazgo de la partitura, desechar la hipótesis que plantea García Lorenzo (2012) en su edición crítica del texto literario de El Caballero de los Espejos $^{13}$, quien la define como una obra lírica con acompañamiento musical. Es más certera la propuesta de Adela Presas, que cataloga este título como una obra dramática con entidad propia que va precedida por un preludio sinfónico (Presas 2007, 285-306).

El episodio de El Caballero de los Espejos, al igual que los demás representados el 10 de mayo de 1905, se adscribe al formato de teatro popular, en un solo acto, propio de la literatura dramática menor. Se acerca al esquema de las funciones por horas, al presentar cuatro títulos breves consecutivos en una misma función, de forma similar a como se organizaban las obras de género chico en los escenarios durante los años del cambio de siglo. Pero esta asignación se debe únicamente a la distribución seccional del evento, puesto que el tono solemne de este acto y su estética no permiten relacionarlo con el casticismo del teatro por horas, su tono mordaz y los chistes frívolos.

Esta hipótesis de la comparación con el teatro por horas queda respaldada hasta el punto de que José Subirá, en su crónica del centenario (1949), expone que la influencia de la zarzuela y el género chico es manifiesta en el homenaje cervantino celebrado en el Teatro Real. En un tono más humorístico, el periódico satírico Gedeón la denomina como «la función del Real y medio la pieza» ${ }^{14}$, en clara alusión al lema «ja real la pieza!», tan utilizado para anunciar estas obras breves en los teatros y cafés por horas en torno a 1880. Esta ironía refleja, además, el ambiente de crispación generado entre la prensa liberal por la descuidada organización del evento y la mala gestión de las entradas, que provocó que varios diarios de esta tendencia se sintiesen desplazados en la celebración y llevasen a cabo una campaña mediática muy crítica en contra de los responsables, especialmente dirigida contra el recién

12. «Espectáculos». Gazeta de Madrid, 15 de mayo de 1905, 628.

13. Tampoco es correcta la fecha del estreno del episodio que apunta el autor, pues si bien es cierto que iba a celebrarse el 9 de mayo, terminó posponiéndose, como se indicó anteriormente.

14. «Los Jueves de Gedeón». Gedeón, Madrid, 11 de mayo de 1905, 2. 
nombrado ministro de Instrucción Pública y Bellas Artes, Carlos María Cortezo, del partido conservador ${ }^{15}$.

Además de relacionarse con el teatro por horas, el acto conmemorativo celebrado en el Teatro Real se inserta también en la tradición decimonónica de las funciones de gala caracterizadas por su elevado carácter patriótico y documentadas por Marina Barba ${ }^{16}$ ya desde el periodo romántico de los años treinta del siglo XIX. Mantiene el mismo patrón que consiste en intercalar composiciones musicales entre los diferentes actos de la representación, con la particularidad de que a diferencia de lo que ocurría anteriormente, en el caso del homenaje cervantino los preludios antecedieron a obras teatrales autónomas y no a cada uno de los actos que constituían un mismo título.

Otra diferencia sustancial con este sistema previo que se puede apreciar en la función del Real es que, excepto por la obertura de Don Giovanni, no se recurre al repertorio operístico a la hora de ocupar los entreactos de los distintos episodios como había ocurrido décadas atrás. Al igual que ocurría en las representaciones teatrales románticas, la misión de estas obras musicales parece ser totalmente funcional, es decir, servían para entretener al público mientras se llevaban a cabo los cambios de decorado de un episodio a otro y para ocultar convenientemente el ruido producido por las tramoyas. Además, desempeñan la tarea de ilustrar y crear una atmósfera en sintonía con la situación dramática de la obra teatral representada, cuyo sentido refuerza e incluso describe. Encaja así con la primera de las funciones que propone Pavis (2002, 306-307) para la música escénica.

La estética compositiva del preludio para El Caballero de los Espejos y del Homenaje a Cervantes no se plantea una posible recuperación patrimonial de la sonoridad musical coetánea al Quijote, que habría sido muy afín a los postulados nacionalistas de reivindicación histórica y musical, amparándose además en la ideología regeneracionista y el sentimiento patriótico sobre los que estaba fundamentado el propio centenario. A juzgar por las crónicas de la función del Real, tampoco hay indicios de que el resto de composiciones perdidas tuviesen intención de recurrir a una estética compositiva historicista que recuperase sonoridades y formas musicales del siglo XVII para el homenaje cervantino. Los ajustados márgenes de trabajo con los que parecen haber contado los autores -la partitura del preludio de Manuel Nieto está firmada el 27 de abril- tampoco debieron ayudar a fijar unos objetivos artísticos que excediesen los usos del teatro musical breve del momento, lo que parece respaldar de nuevo las ideas de los más críticos con el centenario por lo improvisado de su organización.

Sin embargo, Cecilio de Roda (1905) dejó entrever en uno de sus discursos celebrado en el Ateneo de Madrid, también con motivo de la conmemo-

15. «El centenario de "El Quijote"». El País, Madrid, 10 de mayo de 1905, 2.

16. Barba, Marina. 2013. La música en el drama romántico español en los teatros de Madrid (1834-1844). Tesis doctoral, Universidad Autónoma de Madrid. Accesible en: $<$ https://repositorio.uam. es/handle/10486/660374>. 
ración del III centenario, el interés por el patrimonio musical del Siglo de Oro, y menciona las referencias musicales del Quijote, como el soneto a Casildea de Vandalia del capítulo XII que interpreta el bachiller Sansón Carrasco acompañándose a la vihuela. A pesar del alto grado de fidelidad textual que mostraron las adaptaciones literarias de los episodios presentados en la función del Teatro Real ${ }^{17}$, Ramos Carrión, quien reprodujo de forma literal los diálogos entre el bachiller, don Quijote y sus dos escuderos (Vega 2006a; 2006b), decidió omitir en su obra dramática precisamente el fragmento correspondiente a este soneto. En consecuencia, tanto Nieto como Ramos Carrión, encargados del episodio de El Caballero de los Espejos, renunciaron a insertar música incidental en la obra dramática, por lo que queda limitada únicamente a un preludio y unos breves compases reelaborados de los materiales previos para concluir el episodio, lo que no deja de ser paradójico.

El citado soneto del bachiller Carrasco habría sido un buen pretexto para recrear una estructura musical española renacentista, coetánea a la novela cervantina, algo que sí persiguió Cecilio de Roda en el Ateneo y también en la velada conmemorativa celebrada en el Real Conservatorio. En este último acto conmemorativo, además del estreno de nuevas composiciones de temática quijotesca, también se programaron «dos obras para órgano de Antonio de Cabezón, interpretadas por el Profesor de la clase de Órgano, el Sr. Moreno Ballesteros» (Presas 2007, 290).

De Roda $(1905,453-463)$ pretendió recrear el paisaje musical que contextualizó a Cervantes, amparándose en su teoría de que las mismas formas musicales -romances, fantasías, diferencias, sonetos, madrigales o villanescas- que aparecen en los tratados musicales del siglo XVI están presentes también en el Quijote. Al ser personajes con cierta erudición quienes las interpretan, concluye que probablemente estaban en boga entre los círculos culturales más elevados del momento. García Montalván va más lejos cuando afirma que la música está ligada en la novela a la «pompa protocolaria» (2005, 405). El planteamiento historicista es algo en lo que no parecen reparar los compositores participantes en la velada conmemorativa del Teatro Real, y que más allá del limitado tiempo de composición ya mencionado, evidencia una importante disociación musical entre los enfoques teóricos y prácticos a comienzos del XX y cierto desconocimiento de las posibilidades de la novela cervantina incluso entre intelectuales, como Unamuno había declarado (1917).

A pesar del auge de esta conciencia restauradora, la música interpretada en el homenaje no sigue planteamiento alguno de recuperación historicista, sino al contrario. Tanto el preludio de El Caballero de los Espejos de Nieto como el Homenaje a Cervantes se decantan por géneros que han tenido gran aceptación durante el siglo XIX, como son la obertura sinfónica y el himno, sin un aparente interés filológico por la reconstrucción o recreación de la música en la época del Quijote. Las nuevas composiciones muestran un esti-

17. Además de las críticas publicadas en la prensa, los propios autores se esforzaban en dejar constancia de su fidelidad al texto de Cervantes en estas nuevas obras (Álvarez Quintero 1905). 
lo más en sintonía con la tradición decimonónica finisecular, en el sentido de que la recreación se produce desde una postura distanciada e imaginaria que examina la obra cervantina filtrándola a través de los cánones estéticos de la propia época. Es por esta razón por la que se imponen en el centenario formas compositivas adscritas al siglo XIX, en vez de canciones de tono popular incluidas en el transcurso de la obra dramática, de forma similar a como había sido común en el teatro de los siglos XVII y XVIII.

Existieron también en el transcurso de este acto conmemorativo en el Teatro Real ciertas irregularidades en la programación que chocan con el desempeño de una jornada festiva que busca recrear los usos del teatro áureo. Es lo que ocurre, por ejemplo, con la loa que interpretó la actriz María Guerrero, que si bien constituyó un guiño interesante a los usos dramáticos coetáneos de Cervantes, es un género teatral discursivo y laudatorio emplazado al comienzo de la función y no al término, como aparece en este caso y anacrónico al término del XIX, siglo en el que perdió su presencia en los escenarios ${ }^{18}$. Si bien su intención de exaltación nacional, a modo de clímax final de la velada teatral, parece estar bastante clara en esta celebración en el Teatro Real, la colocación de dicha loa al término del programa hace un escaso favor a la hora de vincular este acto con la tradición de los géneros breves del Siglo de Oro.

\section{LA HERENCIA DE LA MÚSICA INCIDENTAL EN EL TEATRO ESPAÑOL DECIMONÓNICO Y SU PERVIVENCIA EN EL CENTENARIO}

Ver a compositores de teatro escribir música incidental para obras dramáticas no es algo inusual. De hecho, en Inglaterra, Arthur Sullivan, cuyo catálogo destaca especialmente por la composición de operetas, escribió también música incidental para representar obras de Shakespeare, como La Tempestad, El mercader de Venecia, Enrique VIII o Macbeth, entre otras. También Francia, y especialmente Alemania, cuentan con una extensa nómina de música incidental durante el siglo XIX gracias a los trabajos de Bizet, Beethoven, Schubert, Weber o Mendelssohn (Serry 1959, 44-53).

También las representaciones teatrales del Siglo de Oro en España contaron con elementos musicales intercalados en las jornadas (Lambea 2006, 125-143). En el siglo XIX se redujo esta tradición áurea, pero la música incidental continuó ligada a la praxis del drama romántico, como ocurrió en el caso de Don Álvaro o la fuerza del sino (1835), del Duque de Rivas, o en El

18. Es muy limitada la bibliografía, las referencias en la prensa y el número de loas que se han documentado en el transcurso del siglo XIX, pero mantienen su posición al comienzo de la función teatral, en línea con los usos teatrales del Siglo de Oro y en contraposición con lo ocurrido en el homenaje cervantino del Teatro Real. Pueden consultarse algunos ejemplos en Carlos Ferrera Cuesta: «Salas y salones: teatro y sociabilidad en la revolución liberal», Libros de la corte, Universidad Autónoma de Madrid: <https://revistas.uam.es/librosdelacorte/article/view/12389>. 
trovador (1836), de García Gutiérrez. Para esta última se escribieron una obertura, la Canción del trovador y el Canto de la gitana (Ribao 2001, 105). Ambos ejemplos ponen de manifiesto hasta qué punto la incorporación de partes musicales incidentales, lejos de constituir un hecho insólito, estaba aceptada en las representaciones de los títulos románticos. Una circunstancia que no parece haber proseguido en el caso del teatro realista y de temática social, ya en la segunda mitad del siglo XIX $^{19}$.

La conmemoración cervantina en el Teatro Real se alinea con la tradición histórica de incorporar fragmentos musicales a la velada dramática, con tres preludios instrumentales de carácter incidental compuestos ex profeso además de la loa y el himno escritos por Fernández Caballero para la ocasión. Supone por tanto una excepción en los primeros años del siglo XX y demuestra hasta qué punto la orientación que se le quiso dar a este acto estaba arraigada en la tradición y tenía un importante peso conservador. La estructura de un programa dramático en distintos títulos en un solo acto parece vincular esta velada con la distribución de las funciones por horas que adquirieron auge a partir del último tercio del siglo XIX, de las que los autores participantes en el homenaje cervantino eran destacados exponentes.

\subsection{La incidencia del poema sinfónico al término del siglo XIX y la temática quijotesca}

Para Pérez Pardo $(2005,179)$, los compositores de principios del XIX se valían de la obertura como género descriptivo, como una herramienta que permitía escribir música programática antes de que el género se desarrollase en extensión y complejidad conforme avanzó el siglo. Las oberturas escritas para el centenario en el Real podrían ajustarse a la idea de que la música de estas obras tiene cierto contenido semántico, pero aquí guarda relación con el texto que la sigue. Una conclusión extraída a partir de las críticas sobre el centenario y El Caballero de los Espejos, el único preludio musical localizado hasta el momento, tras cuyo análisis sí se puede extraer cierta aproximación de sus secciones con la obra dramática a la que precede. Los otros preludios de Bretón y Vives podrían incluirse también en esta línea de composición, ya anacrónica al término del siglo XIX.

A raíz del centenario aparecieron con posterioridad numerosas obras musicales con características similares y temática quijotesca, que se convirtió en uno de los asuntos más destacados dentro de la composición musical española del siglo $\mathrm{XX}^{20}$. Adela Presas $(2007,285-306)$ menciona que este III cente-

19. El mismo Serry $(1959,48)$ comenta cómo el auge de la zarzuela desde la segunda mitad del XIX en los teatros de Madrid desplazó el interés de los compositores desde las partituras de música incidental para teatro hacia fórmulas de teatro musical más ambiciosas.

20. No en vano, Carol Hess $(2001,307-308)$ ha publicado una lista con algunas de las composiciones musicales escritas entre los siglos XVII y XX y en ella hay una importante predominan- 
nario marcó un hito en lo que a la composición de piezas sinfónicas sobre el Quijote se refiere. Es lo que sucedió en el caso del compositor Emilio Serrano, quien formó parte de la Sección de Música de la Academia de Bellas Artes de San Fernando, que organizó algunos de los homenajes celebrados en Madrid para la conmemoración del tricentenario de la primera parte de la novela cervantina y participó activamente en otros actos como el que tuvo lugar en el Real Conservatorio de Música el 18 de mayo de 1905.

Escribió, además, Serrano dos poemas sinfónicos sobre las andanzas del ingenioso hidalgo, La primera salida de don Quijote de La Mancha y Los molinos de viento ${ }^{21}$. El primero de ellos compuesto también en 1905, aunque no llegó a estrenarse finalmente hasta 1912. A juzgar por el análisis de Pérez Ávila ${ }^{22}$, se podría decir que esta primera composición de Serrano se sitúa en una línea similar -ya que no se han localizado todas las partituras-a las obras musicales localizadas de este centenario. Son numerosas las voces que coinciden al comentar que ambas composiciones destacan por su lenguaje nacionalista, heredero de la tradición sinfónica romántica, y albergan también un importante color folklórico (Cuadrado 2010).

La pregunta que interesa en este estudio es si este III centenario cervantino en 1905 y la importancia de la música en sus celebraciones, más allá del homenaje celebrado en el Teatro Real, contribuyeron a que aumentasen las composiciones musicales sobre el protagonista de la novela cervantina en el terreno sinfónico. Los datos aportados por Hess muestran un crecimiento exponencial de las composiciones en España vinculadas temáticamente con el Quijote, al contrario que en Europa. Más que por consecuencia del centenario, la temática cervantina puede verse dentro de un movimiento más amplio de carácter nacionalista vinculado al historicismo, con intenciones de reivindicación patriótica que mira al pasado, en el que se incluye también el propio centenario cervantino y que, en último término, convirtió al Quijote en el icono de la identidad nacional española como parte de la estrategia nacional restaurada (Archilés 2008, 83).

\section{El Homenaje a CERVANTES de MANuEL FernándeZ CABALLERO Y LAS ASPIRACIONES NACIONALISTAS DEL III CENTENARIO}

En 1905 Manuel Fernández Caballero tampoco atravesaba un buen momento en el terreno artístico, pocos meses antes de su muerte. Lo más proba-

cia de obras escritas en la primera mitad del siglo XX. En ella El Caballero de los Espejos figura erróneamente como comedia lírica en un acto, atribuida a Amadeo Vives y no a Manuel Nieto.

21. Custodiadas en la Fundación Juan March y en el Archivo del Real Conservatorio Superior de Música de Madrid, con las signaturas M/418/A y 4/405 respectivamente.

22. Véase Alonso Pérez-Ávila, Beatriz. 2015. El compositor Emilio Serrano y Ruiz (1850-1939): su compromiso regeneracionista con las instituciones del Madrid coetáneo. Estudio de su producción instrumental y sinfónica. Tesis doctoral, Universidad de Oviedo. 
ble es que su participación en el homenaje celebrado en el Teatro Real se debiese a que se trataba de uno de los compositores líricos más destacados del cambio de $\operatorname{siglo}^{23}$. Con una ceguera acusada, había reducido sus trabajos, hasta el punto de que estrenó solo dos obras líricas en el año del centenario. $\mathrm{Su}$ trayectoria profesional era entonces la más extensa y reconocida de todos los que pusieron música a esta conmemoración cervantina, por lo que es comprensible que se le encargase a él, casi como una deferencia por su carrera artística, la labor de componer el fin de fiesta. La apoteosis que terminó la función del Teatro Real con un himno suyo subraya una vez más el grado de abstracción patriótica, el sentido que se le dio al acto y cómo el centenario se utilizó como elemento para instrumentalizar el Quijote y a Cervantes en favor de reforzar los vínculos patrióticos e identitarios de España a comienzos del siglo XX (Guereña 2008, 152). Para ello, introduce un carácter marcial de la partitura, con una sonoridad brillante que consigue gracias a la instrumentación amparada en la sección de metales y el uso del coro, el cual le atribuye un carácter más solemne y marcial a esta composición con respecto a la partitura para El Caballero de los Espejos. Una obra cuyo texto presenta el porvenir indivisible que aguarda a España en sintonía con el reconocimiento internacional que ostentan Cervantes y el Quijote, descrito en términos bélicos que ensalzan la victoria, la gloria y el honor de la nación y el pueblo.

Las partituras localizadas ponen de manifiesto que esta apoteosis, que lleva por título Homenaje a Cervantes, estaba dividida en dos partes: una loa y un himno. Ambas mantienen algunos elementos comunes, sobre todo en lo tocante a la exaltación nacional. Las dos composiciones de Fernández Caba1lero, al igual que el preludio para El Caballero de los Espejos, también están contextualizadas en la tradición decimonónica. Paralelamente al desarrollo de los nacionalismos se incrementó la creación de himnos, tanto oficiales como no oficiales, que aglutinaron las ideologías y pensamientos colectivos que se estaban fraguando en el terreno geográfico, político y social. En el caso de los himnos oficiales, María Nagore apunta su contribución para fraguar «una identidad nacional», pero los mismos códigos presentes en ellos funcionaron también en este himno de Fernández Caballero en el que la gloria de España, de Cervantes y del Quijote son las consignas que más se repiten. La misma autora se refiere a la intención de este tipo de música «como gesto o discurso político» (Nagore 2011, 827), que en este caso pretende ligar el éxito del Quijote y de Cervantes al porvenir de España. Se conservan en esta música de Fernández Caballero las connotaciones patrióticas inherentes al género hímnico, aunque su transcendencia fuese limitada y no excediese los márgenes de la función del Real.

La introducción de un himno como colofón a una representación teatral también tuvo antecedentes en el siglo XIX. Por ejemplo, el Himno de Riego, que completó la función después de una comedia de Martínez de la Rosa en

23. Para una mayor información, puede consultarse Blanco, Nuria. 2015. El compositor Manuel Fernández Caballero (1835-1906). Tesis doctoral, Universidad de Oviedo. 
1820 (Nagore 2011). La retórica del himno de Caballero en homenaje a Cervantes se distancia de la simbología militar que está tan presente en las composiciones hímnicas y no hay en él un lenguaje agresivo ni de lucha o victoria. Sí presenta una elaboración lingüística más compleja de lo que es habitual encontrar en otros himnos y mantiene, no obstante, un componente étnico ${ }^{24}$ importante, que resulta de la apelación histórica para poner en valor la grandeza de España, con Cervantes, el Quijote y, en menor medida el Siglo de Oro, como elementos clave para configurar el «dispositivo retórico» (González Serena 1985, 95) que permitiese la exaltación del ánimo nacional perseguida con la celebración del III centenario.

\begin{tabular}{|c|c|}
\hline \multicolumn{2}{|c|}{ Apoteosis III centenario del Quijote } \\
\hline Homenaje a Cervantes & Himno a Cervantes \\
\hline Rumores múltiples de alboroza & iOh príncipe de príncipes! \\
pasan volannos de gloria & Oh cumbre sobre cumbres, \\
ioh genio vencedor! \\
de pueblo en pueblo, de gente en gente & En pléyade magnífica, \\
llegan vibrantes, llegan aquí. & de soles inmortales \\
Entre sus notas surgen dos nombres. & el más brillante sol. \\
El de Cervantes y don Quijote. & Gloria a ti, oh genio vencedor. \\
Llenan Madrid, llenan España, llenan el & Gloria a ti portentoso Cervantes, \\
mundo. & padre insigne de insigne prosapia. \\
Vítores mil, vítores suenan & iGloria a ti don Quijote sin par!, \\
poblando el aire & enemigo de toda injusticia, \\
vítores suenan! vítores mil. & caballero de todo ideal. \\
iOh hermoso día!, & Canten hoy vuestras glorias los pueblos \\
en opuestos confines del mundo, \\
patria amorosa del gran ingenio, madre feliz. & con un solo tributo de amor, \\
Gloria a Cervantes, gloria al Quijote, & vuestros nombres bendice la patria \\
gloria y honor. & en el nombre del arte español. \\
iGlorioso día, día español! & Gloria a Cervantes, gloria al Quijote. \\
Esplendoroso día de sol. & Gloria y honor... \\
España conmovida & Canten hoy vuestras glorias los pueblos \\
feliz con gloria tanta. & canten hoy. \\
Los cánticos escucha & Pasen sus nombres de siglo en siglo \\
de férvida alabanza. & con el hermoso nombre español. \\
Miradla, miradla. & Como en los montes, \\
& cuando comienza de nuevo el día \\
Oh madre nuestra, oh España madre... & y el sol se asoma. \\
& Redondo es, redondo de rojas llamas \\
& dando a los hombres nueva alegría, \\
& dando a los hombres luz y calor. \\
& Pasan de cumbre en cumbre \\
los refulgentes rayos del sol. \\
Gloria a Cervantes, gloria al Quijote, \\
gloria y honor...
\end{tabular}

FIGURA 1. Referencia del texto que interpreta el coro en la loa y el himno de la apoteosis del III centenario.

24. González Serena $(2005,89-101)$ subraya el necesario nivel de compromiso étnico que subyace en los himnos y la necesidad de circunscribirse al territorio. 
La letra de la loa y el himno de Fernández Caballero son una declaración de intenciones, en el sentido de que además de la exaltación ya comentada de Cervantes, el Quijote y España, también aparecen cuestiones retóricas muy manidas en el imaginario de exaltación patriótica, como la llegada de un nuevo día de gloria, el esplendor del sol que se hace extensible al mayor auge del imperio y la madre patria.

Una alusión de gran valor simbólico que, a nivel glotopolítico, parece tener un marcado sentido colonial que apuesta por el panhispanismo, al menos a nivel emocional, por la presencia de España en América y por no desvincularse de los territorios sobre los que había tenido poder décadas atrás. Con ello, la letra de este himno se adhiere a la tendencia de utilizar la relación con América Latina a comienzos del siglo XX con el fin de beneficiar el nacionalismo en España y favorecer su posición en el ámbito internacional (Núñez y Calero 2019, 1-32). Es importante recordar que la celebración del mismo tricentenario tenía entre sus objetivos estrechar lazos con Hispanoamérica (Storm 1998, 9), y coincidió asimismo con algunas líneas de pensamiento al otro lado del Atlántico (González Aróstegui 2003, 5-18). Es precisamente al término del XIX cuando se articula en España el discurso de la hispanidad, «uno de los valores más rentables y sostenidos de su política exterior» (Navarro 2008, 1) que también aparece de forma muy significativa en las letras de la loa y el himno con los que finalizó la función del Real.

\section{CUESTIONES TÉCNICAS Y DE RECEPCIÓN DE LAS PARTITURAS}

\subsection{Preludio para «El Caballero de los Espejos»}

La partitura de Manuel Nieto para este tercer centenario es un Andante en tempo ternario que presenta una amplia plantilla orquestal en la que sobresale la sección de metales, mientras mantiene las maderas a dos ${ }^{25}$. Una agrupación en deuda con la orquesta de ópera decimonónica por el empleo de cornetines ${ }^{26}$, trombas $^{27}$ y tres trombones (Budden 2001), que quizá cabría vincular también con la música militar y bandística, completamente ajena a los conjuntos musicales renacentistas. Aunque probablemente la elección pudo deberse más bien a una exigencia de la comisión designada por la Academia de Bellas Artes, para que las

25. El manuscrito del Preludio para el episodio del Caballero de los Espejos está firmado y fechado en la portada por el propio compositor, en Madrid, el día 27-04-1905. La partitura que se conserva en el Archivo del Museo Nacional del Teatro de Almagro es un manuscrito autógrafo de Nieto que se encuentra en buen estado físico, sin importantes señales de uso, cuya caligrafía coincide con otras obras del mismo autor custodiadas en la sede de la Sociedad General de Autores de Madrid.

26. Es Felipe Pedrell quien lo relaciona con la orquesta de teatro, siempre asociado con celebraciones populares y escenas festivas. Nieto lo utiliza con frecuencia en su obra lírica. Añade que era frecuente encontrarlo también en la plantilla de las orquestas sinfónicas de los países latinos (Pedrell 1920, 119).

27. Es interesante mencionar el peso que la tradición italiana poseía aún en el terreno compositivo, porque en la partitura autógrafa usa este término tomado del italiano en vez de clarín (Pedrell 1920, 470). 
composiciones se ajustasen a la plantilla de la sinfónica que dirigía Arbós, en vez de a una cuestión estética. Se aleja por ello de las reducidas formaciones para las que Nieto solía escribir en sus obras líricas breves ${ }^{28}$.

No presenta problemas técnicos en lo relativo a los parámetros armónicos, rítmicos o tímbricos, ni adopta procedimientos compositivos innovadores, comparables a los avances que en materia de orquestación presentaba la música sinfónica europea del periodo finisecular, y que se materializó en España a través de los estrenos madrileños de obras de Strauss y Bruckner. Es una escritura bastante vertical, en el sentido de que emplea pasajes homorrítmicos, voces dobladas y no consigue desvincularse de los recursos empleados por la tradición compositiva romántica $(\mathrm{Ej} .1)$.

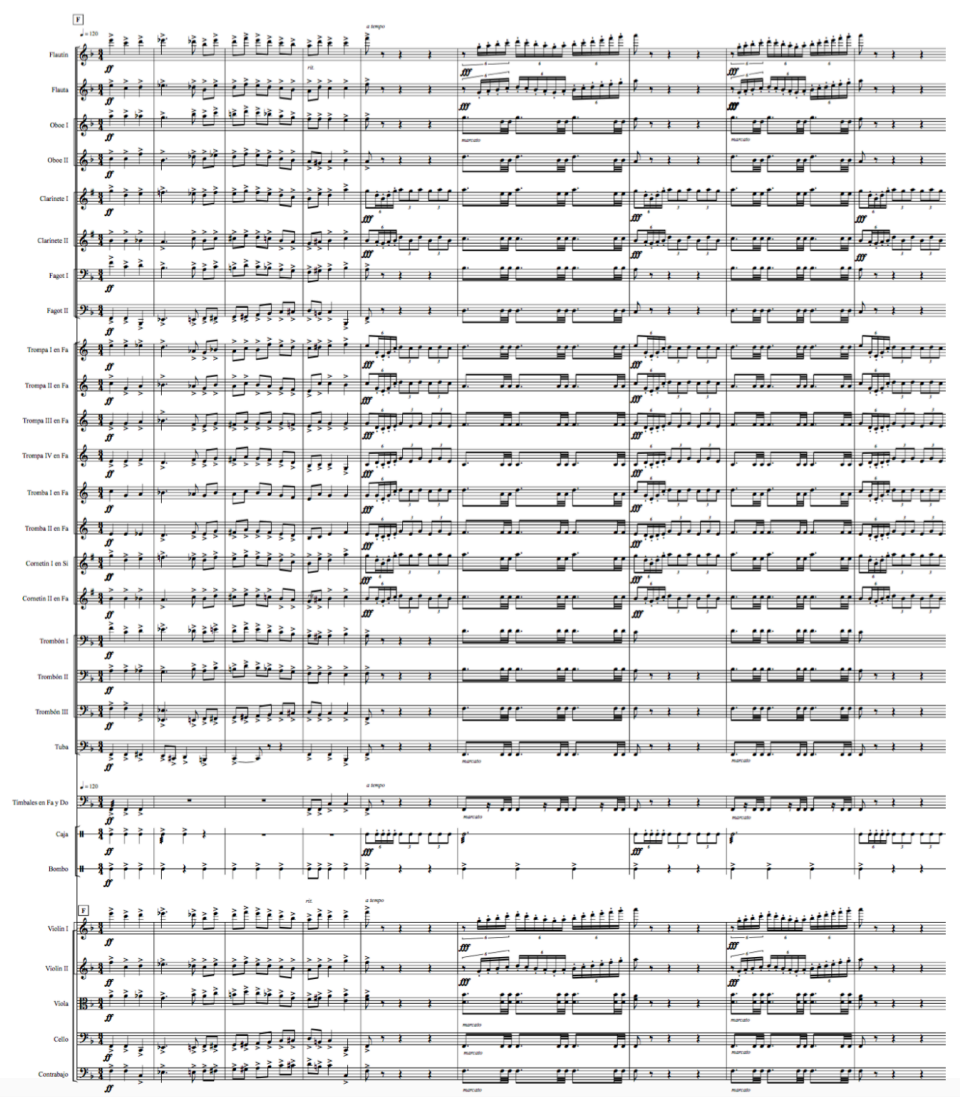

EJEMPLO 1. Fragmento de la partitura general para El Caballero de los Espejos, de Manuel Nieto, donde se puede apreciar toda la plantilla instrumental elegida (compases 81-89).

28. La plantilla en su totalidad está constituida por flautín, flauta, 2 oboes, 2 clarinetes, 2 fagotes, 4 trompas, 2 trombas, 2 cornetines, 3 trombones, trombón bajo, timbales, caja, bombo, violines primeros y segundos, violas, violonchelos y contrabajos. 
Con respecto al análisis temático, no hay en este preludio presencia alguna de elementos populares ni de color local relacionados con la cultura musical hispánica como danzas tradicionales o ritmos característicos, al igual que no presenta correlación entre las distintas secciones ni reutiliza materiales; recursos habitualmente aplicados por Nieto en sus composiciones líricas. Tampoco recurre al desarrollo motívico que aporta uniformidad a la partitura, en el sentido de alinearse dentro de la estética canónica en materia compositiva del siglo XIX, sino que yuxtapone distintas secciones con materiales inconexos, un modo de proceder que podría ampararse en el planteamiento de Kühn (1992), quien propone la diversidad temática como recurso generador de la forma musical.

El esquema formal del preludio (Fig. 2) plantea una correspondencia entre las secciones del preludio y los hechos recogidos en el episodio. Presenta una estructura poliseccional y puede relacionarse con la obertura de concierto que estaba vigente en Europa a principios del siglo XIX, con un planteamiento más libre y flexible en comparación con las oberturas teatrales, que sí empleaban de manera reiterada una estructura formal codificada, adscrita al esquema de la forma sonata sin desarrollo (Temperley 1995).

\begin{tabular}{|c|c|c|c|}
\hline Sección & $\begin{array}{c}\mathrm{N}^{\circ} \text { de } \\
\text { compás }\end{array}$ & Relaciones tonales & $\begin{array}{c}\text { Asociación con el discurso literario } \\
\text { cervantino }\end{array}$ \\
\hline Introducción & cc. 1-12 & Fa M & $\begin{array}{c}\text { Ambiente nocturno en el bosque } \\
\text { frondoso }\end{array}$ \\
\hline I & $13-28$ & Fa M & $\begin{array}{c}\text { Diálogo entre don Quijote y el bachiller } \\
\text { Carrasco. Describen a sus amadas }\end{array}$ \\
\hline II & $29-57$ & Fa M-Do M-Fa M & Amanecer \\
\hline III & $58-76$ & $\begin{array}{c}\text { Mi M-La b M-Fa } \\
\text { m-Fa M }\end{array}$ & Lucha entre los dos caballeros \\
\hline IV & $77-95$ & Fa M & Victoria final de don Quijote \\
\hline Coda & $96-102$ & Fa M & Refuerza la idea de la victoria del héroe \\
\hline
\end{tabular}

FiguRA 2. Estructura del preludio para el episodio del Caballero de los Espejos y las impresiones tomadas de la obra homónima que pretende evocar.

Es posible observar en el transcurso de la acción dramática de la obra teatral un desarrollo lineal que de forma paralela queda reflejado en el preludio, donde continuamente se presentan motivos y temas nuevos sin referencia previa alguna. Este recrea en primer término el ambiente nocturno a través de pasajes cromáticos descendentes y en pianissimo en la sección de cuerda, aunque los procedimientos compositivos utilizados son realmente austeros y no usa el cromatismo con demasiada profusión, ni muestra pretensiones de seguir los postulados wagnerianos (Ej. 2). 


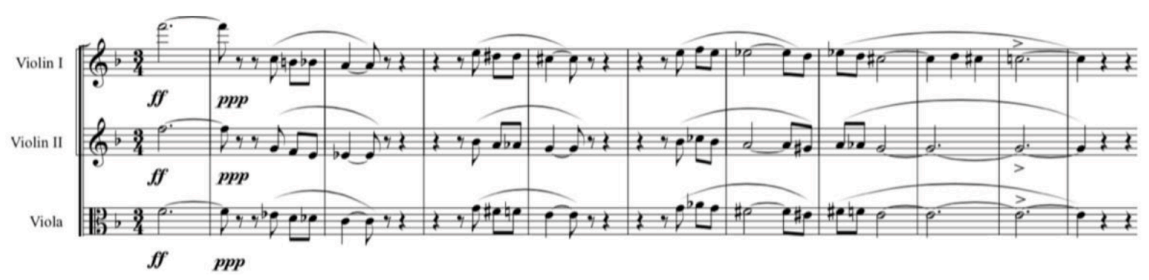

EJemplo 2. Preludio para El Caballero de los Espejos. Sección de cuerda donde se aprecia la sencillez del cromatismo utilizado (cc. 1-11).

De todas formas, sí existe una mayor preocupación por el trabajo cromático que el demostrado por Nieto en sus composiciones para el teatro por horas donde, al contrario que aquí, limita el número de apoyaturas. No hay en este preludio progresión armónica, pues todo él gira en torno a la tonalidad de Fa Mayor, con inflexiones cromáticas amparadas en el uso de acordes secundarios y modulaciones que emplean como recurso frecuente el acorde de dominante secundaria, jugando al mismo tiempo con las tonalidades homónimas.

Cada una de las secciones se construye en torno a una célula rítmica reiterativa y recurrente, sin apenas desarrollo, que en la siguiente sección es sustituida por otra diferente y que impide completamente hablar en esta obra de un desarrollo motívico. Por otro lado, la textura adquiere mayor complejidad conforme avanza el discurso musical y describe el amanecer que sorprende a don Quijote, Sancho y a Sansón Carrasco, ampliando la paleta tímbrica a través de una progresiva incorporación instrumental.

Del mismo modo que ocurre en el episodio dramático, se va gestando aquí la disputa que enfrenta a Sansón Carrasco y don Quijote, coincidiendo con la mayor inestabilidad tonal en la partitura. Trabaja las intervenciones solistas en las maderas, en un carácter cantabile que se prolonga a continuación en la cuerda -mantiene constantemente este dualismo entre las secciones de la orquesta-, desplegando una armonía horizontal que no presenta dificultad técnica ni en el plano compositivo ni en el interpretativo. La presencia de metales y percusión se acentúa conforme se acerca el final, y contribuye a aumentar el dramatismo a través de la intensificación de la densidad sonora, que refleja la tensión de los dos caballeros en la lucha. Las notas acentuadas, así como los motivos rítmicos apuntillados y repetitivos, simbolizan el tono bélico y marcial que impregna la obra (Ej. 1).

Los últimos compases, que conforman la breve coda final, están escritos para interpretarse tras el texto dramático de Ramos Carrión. Reutilizan los mismos motivos rítmicos de carácter marcial y el diseño armónico del final del preludio. Nuevamente en la tonalidad de Fa Mayor, y manteniendo la densidad orquestal con la que había concluido este.

Este interés de Nieto por reflejar musicalmente las situaciones acontecidas en la novela justifica la ausencia de una estructura formal definida, y permite establecer los acontecimientos recogidos en el texto dramático como un pro- 
grama exterior que marca las pautas a través de una serie de señales indicativas que determinan el transcurso de la composición. El contenido extramusical asume por ello la función de ser el impulso inicial en la concepción de la obra y sirve asimismo como hilo conductor, en sintonía con la corriente compositiva decimonónica europea de la música programática (Dahlhaus 1999). No en vano, como se ha comentado previamente, la obertura sinfónica es tomada por algunos estudiosos como la antesala del poema sinfónico (Scholes 2015).

Las malas críticas del homenaje en el Real ${ }^{29}$ y el comentario de Subirá recogido en su crónica de la función comentan la escasa ambición técnica de este preludio. Pero Subirá sí hace alusión de forma positiva al carácter descriptivo que presenta esta partitura con relación al episodio quijotesco al que precede (Subirá 1949). El mismo autor del preludio ratifica esta afirmación en una paráfrasis publicada en un texto recordatorio del centenario que firma Enrique López-Marín (1905), donde el compositor expone cuáles son las imágenes tomadas de la novela que ha querido plasmar en su música. Algunas de ellas recrean el amanecer en el bosque o la disputa entre don Quijote y Sansón Carrasco, en cuya evocación Nieto ha optado por escribir un himno guerrero. Asimismo, López-Marín deja trascender la opinión que el trabajo le merece al propio autor.

El maestro dice que su trabajo es inocente, de una sencillez primitiva, primero por ser suyo - modestia que le honra en extremo-y después porque, en su opinión, el compositor debía huir de todo procedimiento moderno tratándose de un pensamiento lírico dedicado a nuestro rancio y castizo manchego (López-Marín 1905, 31).

Ante la ausencia de más referencias que justifiquen que este preludio se programó en otras ocasiones, lo más probable es que se interpretara exclusivamente en ese acto, más si cabe al tratarse de una obra de encargo con un fin muy bien definido. Resulta significativo el hallazgo de esta partitura por la trascendencia cultural de la celebración del tricentenario y por la información que aporta esta música sobre la promoción institucional del Quijote en 1905, en la que la retórica bélica adquiere, una vez más, relevancia $^{30}$.

29. Especialmente la que suscribe Cecilio de Roda sobre la función del Real, en la que reprende a Vives, Nieto y Caballero por la falta de calidad en sus trabajos: «Teatro español». La Época, 13 de mayo de 1905, 2.

30. Los conflictos con las tropas napoleónicas a comienzos del XIX supusieron que el Quijote se utilizase entonces como un instrumento de propaganda bélica (Caro López 2009). Viendo la repercusión que la Guerra de la Independencia tuvo en términos nacionalistas a lo largo del siglo, es entendible que tras el 98 recurriesen otra vez a los instrumentos propagandísticos de entonces. 


\subsection{Apoteosis «Homenaje a Cervantes»}

Por otro lado, las partituras de Manuel Fernández Caballero custodiadas en el archivo de Almagro ${ }^{31}$ dan indicios sobre el modo en el que la apoteosis se articuló durante el fin de fiesta del homenaje en el Teatro Real. A diferencia de los preludios que lo precedieron, todos ellos instrumentales, lo más destacable es que en esta sección final intervino un coro a seis voces, con tiples $1 .{ }^{\text {as }}$ y $2 .{ }^{\text {as }}$, tenores $1 .{ }^{\text {os }}$ y $2 .{ }^{\text {os }}$, barítonos y bajos ${ }^{32}$, a quienes hay que añadir una banda ${ }^{33}$ y una orquesta sinfónica ${ }^{34}$. Ambas composiciones tienen una estética musical similar, en la que sobresale el ritmo apuntillado y abundan las síncopas y los tresillos, con una línea melódica y un fraseo muy definidos, condicionados por los versos literarios que lo acompañan. Predomina aquí una estética muy solemne tanto en la loa como en el himno, con una escritura homorrítmica entre las partes vocales del coro -a tres voces: tiples, tenores y barítonos- dobladas de forma muy sencilla a la octava, a lo que hay que añadir un acompañamiento orquestal bastante ligero (Ej. 3).

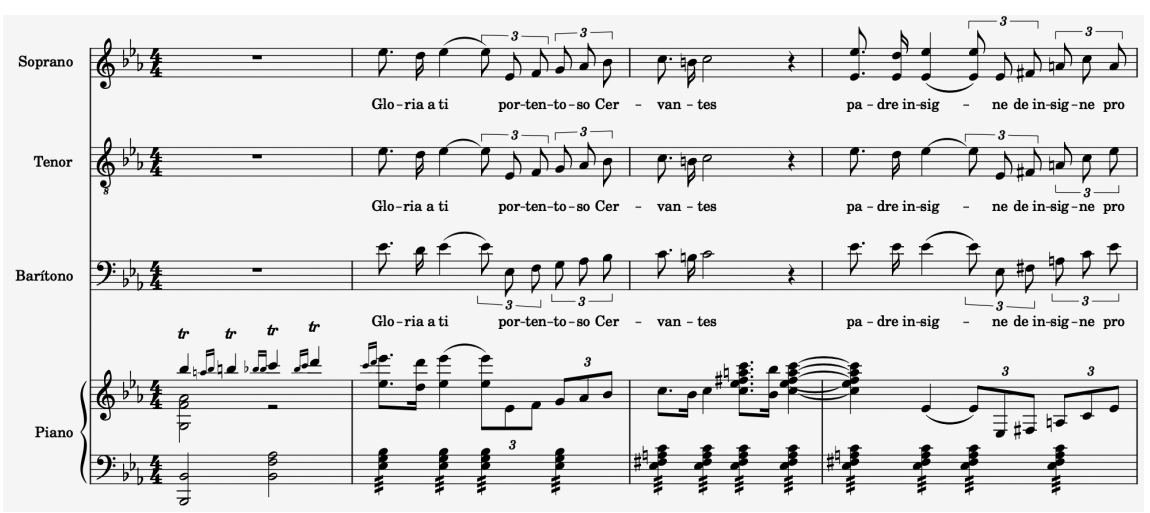

EJEMPLO 3. Apoteosis (continuación) en una reducción para piano extraída de la parte de apuntar, cc. 22-25.

La loa está escrita en compás de 3/4 mientras que el himno final está escrito en tiempo cuaternario, muy utilizado en la literatura hímnica por sus

31. El formato de los materiales localizados varía entre las partituras de Nieto y Fernández Caballero. En el caso del Homenaje a Cervantes escrito por este último, además de las particellas para cada instrumento se han localizado partes de apuntar en reducción para piano, una técnica muy habitual en el desempeño de la interpretación teatral en el siglo XIX, mientras que en el caso del preludio para el Caballero de los Espejos sí se conserva la partitura general de orquesta.

32. Teniendo en cuenta el número de copias que se conservan, se puede hacer una estimación de que la agrupación coral estaba formada por unas 24-25 personas en cada cuerda.

33. La instrumentación para la banda estuvo compuesta por dos fliscornos, dos cornetines, tres trombones, dos clarinetes, trompas en mi bemol o saxofones y un bombardino.

34. Con cuerdas, maderas a dos, 4 trompas, 3 trombones y tuba, 4 cornetines y percusión. 
connotaciones de solemnidad. No aparece en estas obras, como tampoco lo había en el preludio del Caballero de los Espejos, un desarrollo motívico ni una relación cíclica entre las secciones musicales en las que un tema ya presentado reaparece. Fernández Caballero coincide estilísticamente con Nieto en que el procedimiento utilizado al escribir esta música fue la yuxtaposición de secciones musicales y la presentación continua de nuevos materiales, saliéndose así de los cánones más tradicionales de la música sinfónica europea del siglo XIX, lo que explica en parte las malas críticas recibidas tras la función del Teatro Real.

Predomina la uniformidad melódica en las líneas vocales para este fin de fiesta, con una escritura hímnica en la que la declamación de la parte literaria y la difusión del mensaje textual son lo más importante, dejando la música en un segundo plano. Existen también algunos momentos puntuales en los que aparece una textura musical más imitativa que coincide con los momentos de mayor exaltación nacional y de los logros cervantinos. Dentro de este himno a Cervantes hay dos secciones diferenciadas: la primera, allegro no mucho [sic] y otra más movida, allegro poco più mosso, que comienza con la entrada de la banda de música y que tiene una función de coda final. Tanto la supuesta loa como este himno final presentan una estructura de alternancia estrófica, con la particularidad de que en términos musicales no aparece un estribillo que se repita íntegramente como tal. La articulación de los materiales del Homenaje a Cervantes localizados en Almagro, basándose en las partituras, la recepción y la bibliografía, quedaría distribuida como se muestra a continuación (Fig. 3).

\begin{tabular}{|c|c|c|c|}
\hline Composición & Teтро & Secciones & Descripción \\
\hline \multirow{4}{*}{$\begin{array}{c}\text { Homenaje a Cervantes } \\
\text { (Loa) }\end{array}$} & \multirow{4}{*}{ Andante } & Introducción & \multirow{4}{*}{$\begin{array}{l}\text { Escrito en compás } \\
\text { de } 3 / 4, \text { muy } \\
\text { frecuente en los } \\
\text { himnos, y con } \\
\text { figuración } \\
\text { apuntillada. } \\
\text { Connotaciones } \\
\text { hímnicas y militares } \\
\end{array}$} \\
\hline & & 1. ${ }^{\mathrm{a}}$ Estrofa & \\
\hline & & Estribillo & \\
\hline & & Coda & \\
\hline \multirow{3}{*}{$\begin{array}{c}\text { Apoteosis } \\
\text { (Himno) }\end{array}$} & Allegro non troppo & $\begin{array}{l}\text { Introducción } \\
\text { 1. }{ }^{\mathrm{a}} \text { Estrofa } \\
\text { Estribillo }\end{array}$ & $\begin{array}{l}\text { Se repite el mismo } \\
\text { tema, con tresillos y } \\
\text { apuntillado, de } \\
\text { forma reiterada con } \\
\text { pequeñas variaciones }\end{array}$ \\
\hline & Dolce & 2. ${ }^{\mathrm{a}}$ Estrofa & $\begin{array}{l}\text { Cambio de tonalidad } \\
\text { y de carácter }\end{array}$ \\
\hline & $\begin{array}{l}\text { Allegro poco più } \\
\text { mosso }\end{array}$ & Estribillo reelaborado & $\begin{array}{l}\text { Se incorpora la } \\
\text { banda de música }\end{array}$ \\
\hline
\end{tabular}

FiguRA 3. Relación formal por secciones de la loa y el himno compuestos por Fernández Caballero para conmemoración del Quijote en el Teatro Real. 
El aspecto político es el que más sobresale en las dos composiciones escritas por Fernández Caballero, y esta es su principal diferencia con el resto de partituras estrenadas en la misma noche, cuya tendencia iba más orientada a subrayar los episodios literarios de la novela cervantina, a juzgar por lo ocurrido con El Caballero de los Espejos.

\section{CONCLUSIONES}

La estrecha relación entre retórica bélica en torno al III centenario y la exaltación nacional destaca en la estética y la forma de las partituras musicales localizadas de la velada conmemorativa en el Teatro Real. El tono de este homenaje presenta cierta connotación militar, presente a través de la música que se vale de ella como vehículo de cohesión que pretende actuar al servicio institucional. La elección de las formas musicales, las figuraciones y la sonoridad de los materiales localizados respaldan esta postura. Además, la improvisación y la urgencia con las que parece haberse preparado la función en el Teatro Real para el centenario afectó a la calidad e incluso a la elección del formato de las composiciones localizadas, a lo que habría que sumar que los compositores Manuel Fernández Caballero y Manuel Nieto orientaron sus carreras en el ámbito del teatro musical hispánico y no en la línea de la composición orquestal europea al término del XIX, por lo que era esperable el choque de sus obras para el centenario con la opinión de la crítica. La popularidad y el favor del público que alcanzaron ambos en el terreno del género chico finisecular jugó un papel determinante en su participación en el tricentenario.

En términos estilísticos y musicales, las dos partituras de Nieto y Caballero estrenadas en la función conmemorativa del Real tienen en común que no utilizan sonoridades andalucistas ni tienen aspiraciones para plasmar musicalmente las andanzas de don Quijote en la novela cervantina que se puedan plegar a la estética nacional pintoresquista. Establecen una línea de composiciones, y en especial de poemas sinfónicos, que no recurren a tópicos andalucistas para representar el carácter español del Quijote.

La reivindicación nacionalista que trasciende en las dos partituras localizadas pone énfasis en representar el pasado pero usando las técnicas, las formas y los usos compositivos coetáneos, extraídos de la tradición decimonónica más inmediata y que eran familiares a los autores participantes. Tampoco puede decirse que en el preludio del Caballero de los Espejos de Nieto ni en la loa y el himno de Fernández Caballero haya inquietud alguna por la reelaboración del folclore, que sí tuvo un peso importante en las composiciones de músicos más canónicos tras el cambio del siglo. 


\section{BIBLIOGRAFÍA CITADA}

Álvarez Quintero, Serafín y Joaquín Álvarez Quintero. 1905. La aventura de los galeotes. Adaptación escénica del capítulo XXII de la primera parte de Don Quijote de La Mancha. Madrid: R. Velasco.

Álvarez Quintero, Serafín y Joaquín Álvarez Quintero. 1911. Los galeotes. Comedia en cuatro actos. Madrid: R. Velasco.

Archilés, Ferrán. 2008. «Vivir la comunidad imaginada. Nacionalismo español e identidades en la España de la Restauración». Historia de la educación. Revista interuniversitaria 27: 57-85.

Budden, Julian. 2001. The Operas of Verdi. Oxford: Clarendon Press.

Cabrera, Antonia Javiera. 2019. «La presencia de la música en Don Quijote». En La multiplicidad de enfoques en Humanidades: actas de las VIII Jornadas de Investigación de la Facultad de Filosofia y Letras de la Universidad de Alicante, ed. Ernesto Cutillas, 81-88. Murcia: Facultad de Filosofía y Letras. Accesible en: <http://hdl.handle. net/10045/91601>.

Caro López, Ceferino. 2009. «Don Quijote en la guerra del Francés». Anales Cervantinos 41: 39-61. https://doi.org/10.3989/anacervantinos.2009.002

Chaparro, M. a Ángeles. 2013. «La cobertura española del III centenario del Quijote. Análisis del valor simbólico de la novela y su protagonista en la prensa de 1905». Doxa comunicación: revista interdisciplinar de estudios de comunicación y ciencias sociales 16: 85-104.

Cortizo, M. ${ }^{a}$ Encina y Ramón Sobrino. 2010. «Visiones del Quijote desde la zarzuela del siglo XX». En Visiones del Quijote en la música del siglo XX, ed. Begoña Lolo, 155-202. Madrid: Centro de Estudios Cervantinos.

Cuadrado, M. ${ }^{a}$ Dolores. 2010. «La recepción de la figura de don Quijote en la Orquesta Filarmónica de Madrid entre 1915-1936». En Visiones del Quijote en la música del siglo XX, ed. Begoña Lolo, 253-278. Madrid: Centro de Estudios Cervantinos.

Dahlhaus, Carl. 1999. La Idea de la música absoluta. Barcelona: Idea Books.

De Roda, Cecilio. 1905. «Las canciones del Quijote». En El Ateneo de Madrid en el III Centenario de la publicación de El ingenioso hidalgo Don Quijote de la Mancha: conferencias, 453-463. Madrid: Ateneo de Madrid.

Encabo, Enrique. 2008. Música y nacionalismos en España. El arte en la era de la ideología. Barcelona: Erasmus Ediciones.

Fusi, Juan Pablo. 2003. La patria lejana: el nacionalismo en el siglo XX. Barcelona: Taurus.

García Lorenzo, Luciano. 2012. El Caballero de los Espejos de Ramos Carrión. Alcalá de Henares: Centro de Estudios Cervantinos.

García Montalván, Antonio. 2005. «Lo sonoro, función y símbolo en Don Quijote. Materiales para un acercamiento a su mundo sonoro». Nasarre. Revista aragonesa de Musicología. Actas del VIII Congreso Internacional de la Sociedad Ibérica de Etnomusicología 1(1): 389-441.

González Aróstegui, Mely del Rosario. 2003. «Fernando Ortiz y la polémica del panhispanismo y panamericanismo en los albores del siglo XX en Cuba». Revista de Hispanismo Filosófico 8: 5-18. Accesible en: <http://www.cervantesvirtual.com/obra/ fernando-ortiz-y-la-polmica-del-panhispanismo-y-el-panamericanismo-en-los-alboresdel-siglo-xx-en-cuba-0/>.

González Serena, José Antonio. 2005. «El himno de Riego. Música, política y patrimonio». Nasarre. Revista aragonesa de Musicología. Actas del VIII Congreso Internacional de la Sociedad Ibérica de Etnomusicología 1(1): 89-101. 
Guereña, Jean Luis. 2008. «UUn icono nacional? La instrumentalización del Quijote en el espacio escolar del primer tercio del siglo XX». Bulletin Hispanique 110(1): 145-190.

Hess, Carol A. 2001. Manuel de Falla and modernism in Spain, 1898-1936. Chicago: The University of Chicago Press.

Kühn, Clemens. 1992. Tratado de la forma musical. Barcelona: Labor.

Lambea, Mariano. 2006. «Música para teatro en los cancioneros poético-musicales del Siglo de Oro». En En torno al Teatro del Siglo de Oro. Jornadas XVIII-XX, eds. Antonio Serrano y Olivia Navarro, 125-143. Almería: Instituto de Estudios Almerienses.

Lolo, Begoña. 2006. «El Quijote en la música europea: encuentros y desencuentros». Edad de Oro 25: 317-332.

Lolo, Begoña. 2007. «Cervantes y el Quijote en la música española (siglos XVII-XIX): una difícil recepción». En Cervantes y el Quijote en la música: estudios sobre la recepción de un mito, coord. Begoña Lolo, 117-150. Madrid: Centro de Estudios Cervantinos.

Lolo, Begoña. 2010. «Interpretaciones del ideal cervantino en la música española del siglo XX». En Visiones del Quijote en la música del siglo XX. Tradición y vanguardia, coord. Begoña Lolo, 83-108. Madrid: Centro de Estudios Cervantinos.

Lolo, Begoña y Adela Presas. 2014. «Cervantes y el Quijote en la música: pasado y presente». En Comentarios a Cervantes. Actas selectas del VIII Congreso Internacional de la Asociación de Cervantistas, coords. Emilio Martínez Mata y María Fernández Ferreiro, 153-166. Oviedo: Asociación de cervantistas.

López, Francisco Manuel. 2017. «Manuel Fernández Caballero en torno al III centenario del Quijote: Homenaje a Cervantes». En "Trabajos que nacen del espíritu”. Estudios sobre músicas cervantinas, eds. Paulino Capdepón y Juan José Pastor, 325-342. Madrid: Editorial Alpuerto.

López-Marín, Eduardo. 1905. Centenario tercero de la publicación del inmortal libro «El ingenioso hidalgo Don Quijote de La Mancha». Madrid: Imprenta de Antonio Marzo.

López Roldán, Elías. 2005. «De cómo se celebró el III centenario del Quijote». Barcarola: revista de creación literaria 65-66: 273-278.

Morales-Cañadas, Esther. 2011. «La expansión y propagación del Quijote a través de la música». En Visiones y revisiones cervantinas: actas selectas del VII Congreso Internacional de la asociación de Cervantistas, coord. Christoph Strosetzki, 639-650. Madrid: Centro de Estudios Cervantinos.

Moreno, Javier. 2007. «El rey patriota. Alfonso XIII y el nacionalismo español». En Monarquía y República en la España contemporánea, coord. Ángeles Lario, 269-294. Madrid: Biblioteca Nueva / Universidad Nacional de Educación a Distancia.

Nagore, María. 2011. «Historia de un fracaso: el "himno nacional" en la España del siglo XIX». Arbor 187(751): 827-845. https://doi.org/10.3989/arbor.2011.751n5002

Navarro, Santiago Juan. 2008. «Del imperialismo político al neocolonialismo cultural: el mito de la Madre Patria y sus proyecciones mediáticas». En Actas del I Congreso internacional de literatura, arte y cultura en la globalización, ed. Carlos Borro, 1-9. Buenos Aires: La bohemia. Accesible en: <https://fdocuments.ec/document/delimperialismo-politico-al-neocolonialismo-cultural-santiago-juan-navarro.html >. Fecha de acceso: 19 de mayo de 2021.

Núñez García, Víctor Manuel y M. ${ }^{a}$ Luisa Calero. 2019. «América Latina y el nacionalismo español. Alfonso XIII frente al movimiento hispanoamericanista (1902-1929)». Secuencia: revista de historia y ciencias sociales 103: e-1561. https://doi.org/10.18234/secuencia.v0i103.1561

O’Learly, Brendan. 2000. «El diagnóstico de Gellner sobre el nacionalismo: una visión general crítica, o ¿qué sigue vivo y qué está muerto en la filosofía del nacionalismo 
de Gellner?». En Estado y nación: Ernest Geller y la teoría del nacionalismo, coord. John A. Hall, 64-126. Madrid: Akal.

Pascual, Pedro. 1999. «El 98 de Don Quijote». En Actas del VIII Coloquio Internacional de la Asociación de cervantistas, coord. José Ramón Fernández de Cano y Martín, 143-158. El Toboso: Asociación de cervantistas. Accesible en: $<$ https://cvc.cervantes. es/literatura/cervantistas/coloquios/cl_VIII/cl_VIII_13.pdf $>$.

Pastor Comín, Juan José. 2005. «Que sin duda don Quijote quiere darnos música, y no será mala, siendo suya». Contrastes. Revista cultural 38: 19-24.

Pavis, Patrice. 2002. «Música escénica». En Diccionario del Teatro: Dramaturgia, Estética, Semiología, 306-307. Barcelona: Paidós.

Pedrell, Felipe. 1920. «Cornetín». En Diccionario Técnico de la Música, 2." ed., 119. Barcelona: Isidro Torres Oriol.

Pedrell, Felipe. 1920. «Tromba». En Diccionario Técnico de la Música, 2.a ed., 470. Barcelona: Isidro Torres Oriol.

Pérez-Magallón, Jesús. 2020. «Galleguismo y quijotismo: a propósito del tricentenario del Quijote». Anales Cervantinos 52: 119-143. https://doi.org/10.3989/anacervantinos.2020.005

Pérez Pardo, Juan Pedro. 2005. «Música programática: Don Quijote como ejemplo de senso traslato en un poema sinfónico de Richard Strauss». En ¿Qué Quijote leen los europeos?, coord. Miguel Ángel Vega Cernuda, 179-191. Madrid: Universidad Complutense de Madrid. Accesible en: <https://cvc.cervantes.es/lengua/iulmyt/pdf/quijote/16_perez. pdf $>$.

Presas, Adela. 2007. «1905: la trascendencia musical del tercer centenario». En Cervantes y el Quijote en la música. Estudios sobre la recepción de un mito, ed. Begoña Lolo, 285-306. Madrid: Centro de Estudios Cervantinos.

Ribao, Montserrat. 2001. «Música y cantos en los dramas románticos españoles: pertinencia espectacular y funcionalidad semántica». Cuadernos de Ilustración y Romanticismo. Revista del Grupo de Estudios del siglo XVIII 9: 103-119.

Sánchez, Víctor. 2002. Tomás Bretón. Un músico de la Restauración. Madrid: ICCMU.

Sawa, Miguel y Pablo Becerra. 1905. «Las fiestas del centenario». En Crónica del Centenario de Don Quijote, 105-117. Madrid: Establecimiento tipográfico de Antonio Marzo.

Scholes, Percy, Judith Nagley y Kenneth Chalmers. «Symphonic poem». En The Oxford Companion to Music, ed. Alison Latham. Oxford: Oxford University Press. Accesible en: <https://www.oxfordreference.com/view/10.1093/acref/9780199579037.001.0001/ acref-9780199579037-e-6593>.

Serry, Carlos. 1959. «Música para teatro». Revista musical chilena 13 (63): 44-53.

Storm, Eric. 1998. «El tercer centenario de Don Quijote en 1905 y el nacionalismo español». Hispania. Revista española de Historia 58(199): 625-654. https://doi. org/10.3989/hispania.1998.v58.i199.651

Subirá, José. 1949. Historia y anecdotario del Teatro Real. Madrid: Plus Ultra.

Temperley, Nicholas. 1995. «Overture». En The New Grove Dictionary of Music and Musicians, ed. Stanley Sadie, vol. 14, 33-35. Londres: Macmillan Publishers.

Unamuno, Miguel de. 1916. Ensayos. Madrid: Publicaciones de la Residencia de Estudiantes. Accesible en: <https://archive.org/details/ensayos05unam/page/214/ mode/2up>.

Vega, Pilar. 2006a. «Hasta dentro de cien años: el homenaje del teatro al Tercer Centenario del Quijote (I parte)». Espéculo. Revista de Estudios Literarios 32. Accesible en: $<$ http://www.ucm.es/info/especulo/numero32/quicente.html>. 
Vega, Pilar. 2006b. «Hasta dentro de cien años: el homenaje del teatro al Tercer Centenario del Quijote (II parte)». Espéculo. Revista de Estudios Literarios 33. Accesible en: $<$ http://www.ucm.es/info/especulo/numero33/qpvega2.html $>$.

Weber, Eckhard. 2005. «Don Quijote en la historia de la música». En Actas del congreso "El Siglo de Oro en el nuevo milenio"”, coords. Carlos Mata y Miguel Zugasti, 17431756. Pamplona: Ediciones Universidad de Navarra.

Recibido: 10 de noviembre de 2020 Aceptado: 18 de abril de 2021 